O. M. Dubovoy ${ }^{1}$, orcid.org/0000-0002-2843-1879,

A. A. Karpechenko ${ }^{1}$, orcid.org/0000-0002-7543-4159, M. M. Bobrov ${ }^{1}$, orcid.org/0000-0002-9098-6912, O.S. Gerasin ${ }^{1}$, orcid.org/0000-0001-5107-9677, O.O. Lymar' ${ }^{2}$, orcid.org/0000-0002-0301-7313

\title{
ELECTRIC ARC SPRAYING OF CERMET COATINGS OF STEEL 65G-TIC SYSTEM
}

Purpose. Substantiation of the possibility of obtaining composite cermet electric arc coatings using TiC powder as a strengthening phase, determination of their physical and mechanical properties.

Methodology. The microstructure of the composite cermet electric arc coatings was studied by computer metallography using a ZEISS Gemini SEM 500 scanning electron microscope. The chemical composition was determined by X-ray spectral analysis; phases were identified by measuring their microhardness on a PMT-3 device. The bond strength of the obtained coatings was determined by the method of "pulling out the pintle" on a tensile testing machine UMM-5.

Findings. Composite cermet coatings of the steel $65 \mathrm{G}-\mathrm{TiC}$ system were obtained by the electric arc spraying using TiC powder in a free state. The influence of the technological parameters of spraying on the amount of the carbide phase in the coating was established, and their microstructure was investigated. The porosity, microhardness of the phases in the coating and its bond strength were determined.

Originality. For the first time, composite cermet electric arc coatings of the steel $65 \mathrm{G}-\mathrm{TiC}$ system were obtained by using a powder of strengthening phase in a free state. Their microstructure, microhardness and bond strength were investigated. The technological spraying modes of electric arc coatings have been established, which provide the optimal content of the strengthening phase to achieve their maximum bond strength with substrate.

Practical value. The application of the research results obtained in the work, namely, the determination of the optimal technological parameters of spraying for the formation of cermet electric arc coatings with the maximum level of physical, mechanical and operational properties, makes it possible to meet the requirements for the restoration and hardening of worn surfaces. This leads to an increase in the service life of parts not only in mining, but also in other industries.

Keywords: electric arc spraying, cermet coatings, titanium carbide

Introduction. The level of industrial development at the beginning of the $21^{\text {st }}$ century is characterized by an increased intensity of modes of operation of machines and mechanisms. The mining industry was no exception. The equipment used is operated under conditions of increased abrasive wear in combination with pressure, vibration, shock, which can lead not only to a decrease in productivity, loss of profit, but also to emergency situations. The operational properties of parts and mechanisms, as well as their working time, are determined mainly by the physical and mechanical properties of the surface. As the statistical analysis shows, the majority of machines $(85-90 \%)$ fail not due to breakage, but as a result of wear of the surfaces of individual parts. In practice, there are various ways to solve the problem of wear of parts of mining equipment, but the most profitable and promising is the deposition of protective coatings on the working surfaces using the methods of thermal spraying. This is explained by the fact that when the wear of the part is eliminated, the mass of the sprayed material is usually $2-4 \%$, and the cost of repair does not exceed $10-30 \%$ of the cost of the new one.

A wide variety of operational factors affecting parts requires the creation of coatings that ensure the performance of products, often in extreme conditions. The development of technology, on the one hand, and successes in the field of creating materials, on the other, are responsible for progress in the field of thermal spray technologies, which provide coatings deposition from heated and accelerated particles of the sprayed material using a high-temperature gas jet, upon collision of which with the base or sprayed material, their connection occurs.

(C) Dubovoy O. M., Karpechenko A.A., Bobrov M.M., Gerasin O.S., Lymar O. O., 2021
However, coatings obtained by traditional spraying technologies do not always provide a sufficient level of physical, mechanical and operational properties required for the efficient operation of parts and mechanisms under specified conditions. To solve this problem, composite cermet coatings have been increasingly used recently, which consist of a metal matrix, based on nickel, cobalt or iron alloys, and a hardening phase, mainly tungsten, chromium or titanium carbides. It should be noted that among the thermal spraying methods, electric arc spraying is characterized by simplicity, high productivity, energy efficiency and material utilization factor. The relative cost of electric arc coatings is 3-10 times lower than that obtained by other methods of thermal spraying. In addition, the results of recent studies indicate the possibility of expanding the range of materials from which the coating is formed and a significant increase in their physical, mechanical and operational properties.

Literature review. To deposit composite cermet coatings, atmospheric plasma $[1,2]$, high velocity oxygen-fuel, high velocity air-fuel (HVOF, HVAF) [3-5] or cold spraying [6, 7] are used. The disadvantages of coatings deposited by these methods include their high cost associated with the use of flammable and inert gases; obligatory use of expensive equipment for application; high requirements for the qualifications of workers. As for the electric arc cermet coatings, they are obtained by spraying flux-cored wires of various compositions [8-10].

The use of special flux-cored wires for electric arc spraying has made it possible to drastically expand the scope of this method, to obtain composite coatings, whose wear resistance is not inferior to the best plasma coatings. A significant improvement in the mechanical, corrosion-resistant and tribological characteristics of the renewable surface of the product 
can be achieved by using composite coatings, using dissimilar wires for electric arc spraying - flux-cored wires, solid wires, as well as their combination.

The highest quality composite coatings, which have improved service properties, are obtained by using two or three dissimilar solid wires. Such pseudo-alloy coatings are characterized by high mechanical, tribological and corrosion-resistant properties due to obtaining a dense coating structure, increased bond and cohesive strength. A significant disadvantage of pseudo-alloy coatings is that they are obtained only from conductive wires. When using wire as a sprayed material, the continuity of the process is disrupted, this leads to a decrease in service properties.

The use of flux-cored wires to obtain composite coatings leads to increased porosity, which negatively affects the complex of physical and mechanical properties of coatings. This increases their cost. Wear-resistant composite coatings are characterized by a high level of residual stresses, which causes the appearance of micro-and macrocracks, as well as insufficient bond and cohesive strength. This is especially typical for coatings of considerable thickness, which are re-ground to the repair dimensions during machining. Currently, there is insufficient experimental data on the development and creation of composite coatings that would combine a high level of wear resistance with sufficient plasticity, bond and cohesive strength. There is no data on the relationship between the composition of the charge of flux-cored wires and their combinations with wires of the solid cross-section with the tribological properties of composite coatings, which hinder their widespread use in production.

The purpose of this work is to study the possibility of obtaining cermet electric arc coatings of the steel $65 \mathrm{G}-\mathrm{TiC}$ system using a hardening phase in the free powder form and to determine their physical, mechanical and operational properties.

Results. The object of research was selected, which was electric arc composite cermet coatings obtained by spraying solid wire of $65 \mathrm{G}$ grade and titanium carbide powder onto a substrate made of high-quality carbon structural steel 45 . For spraying cermet electric arc coatings, a KDM-2 unit was used, equipped with an EM-14M gun with a modernized spray head cap (Fig. 1), designed for uninterrupted supply of powder particles to the high-temperature arc discharge zone [11].

The modernization of the cap of the spray head of the EM-14M electric arc gun consisted in changing the design of



Fig. 1. The modernized cap of the spray head of the EM-14M electric arc spray gun:

1 - bunker cover; 2 - bunker; 3 -dosing device; 4-control lever; 5 - screw for adjusting the dosing device; 6 - cap; 7 - adapter; 8 - protective screen; 9 - nozzle; 10 - insulator the main working nozzle 9 and the protective screen 8 . The main working bronze nozzle 9 has an annular chamber with holes for powder supply, whose outlets are located at an acute angle to the axis of the high-temperature jet and are directed towards sprayed surface. The opening of the main working nozzle, from which the working compressed gas flows out, has a smaller diameter than the opening from which the conveying openings for feeding the powder exit. The working nozzle is installed in insulators 10 and pressed by a protective screen to the cap 6 of the electric arc gun. The protective shield 8 also contains an annular chamber with holes, the outlets of which are at an acute angle to the axis of the high-temperature jet and directed towards the sprayed surface, through which additional compressed gas is supplied. Due to the supply of additional compressed gas from the holes of the protective screen, a vacuum is created, which leads to an increase in the flow rate of the working gas from the nozzle 9 , which facilitates the evacuation of liquid metal from the ends of the wire electrodes, and also gives it additional acceleration at the initial section of the heterophase high-temperature jet.

The additional supply of compressed gas from the holes in the protective shield allows increasing the velocity of particles in the main section of the high-temperature jet. When the control lever 4 is pressed, the powder is supplied due to atmospheric injection. Powder consumption is regulated by screw 5 . To increase the powder consumption, a transport gas is supplied through the hole in the lid of the hopper 1, which transports the powder particles directly to the arc discharge zone, for better heating and mixing with liquid metal particles. Due to the additional supply of compressed gas that flows out of the holes of the protective screen, the high-temperature flow is compressed; particles of molten metal and powder are accelerated in it, the jet opening angle decreases, which leads to an increase in the utilization rate of the material, especially when spraying on parts of the "shaft" type. An increase in the particle velocity in a high-temperature flow leads to a greater degree of deformation of the sprayed particles, a decrease in porosity and, as a consequence, to an increase in the mechanical and operational properties of composite electric arc coatings.

To prevent the adhesion of molten particles to the bronze working nozzle, a wire with a diameter of $1.2 \mathrm{~mm}$ was used.

Before spraying, titanium carbide powder was heated in a drying oven at a temperature of $150{ }^{\circ} \mathrm{C}$ for 3 hours.

The sieve classification of the applied powder was carried out on a laboratory installation model 029 , using a grid of numbers 004 and 008 according to GOST 6613-86. As a result of sieving, a powder with a fraction of $40-80 \mu \mathrm{m}$ was isolated, which was used to obtain a composite cermet electric arc coating.

The use of a finer powder for spraying is usually accompanied by an improvement in the filling of the coating, which leads to an increase in density and a decrease in porosity. The coating structure becomes more uniform. However, in practice, the minimum particle size during thermal spraying should be at least $40 \mu \mathrm{m}$, which is due to a number of reasons for introducing the powder into the spray gun. Their preparation and alignment in size (fractions) is difficult. Dispersed particles are more prone to the formation of conglomerates when they are fed by a carrier gas flow. Such particles can evaporate during spraying as a result of getting into the high-temperature zone of the arc discharge, quickly lose their velocity and do not reach the sprayed surface. Large particles are poorly melted in a high-temperature flow, which also negatively affects the quality of thermal sprayed coatings. The spraying of powder with a different particle size distribution causes a violation of the uniformity of the coating due to the unequal velocity of movement and penetration of small and large particles in the high-temperature flow.

The surface preparation of the samples, immediately before spraying, was carried out using a 026-7 "Remdetal" device for jet-abrasive treatment. Electrocorundum grade 7B, grinding grain number 125 was used as an abrasive. 
The abrasive blasting of the surface intended for spraying was carried out in the following technological mode:

- compressed air pressure, mpa 0.4-0.6;

- distance from the nozzle exit to the processed surface, mm 100-150;

- nozzle diameter, $\mathrm{mm} \mathrm{12;}$

- the angle of incidence of the jet on the treated surface, degrees 60-90;

- linear speed of gun movement, $\mathrm{mm} / \mathrm{min} 50-400$.

The processing was carried out in several passes.

The quality control of the treated surface was carried out visually. The treated surface of steel plates and samples intended for studying the microstructure and determining the bond strength of coatings to the substrate, respectively, after abrasive blasting had a grayish-matte shade. The roughness of the processed surface was $R z=38-75$ microns.

Spraying of composite coatings was carried out on plates of 45 carbon steel with dimensions $50 \times 20 \times 5 \mathrm{~mm}$. This steel is intended for the manufacture of bushings, gears, crankshafts and camshafts, spindles, bandages, cylinders, rods, and so on.

The thickness of the coatings was determined by measuring the samples before and after spraying with a caliper. The thickness of the sprayed coatings was $1.5-2.0 \mathrm{~mm}$.

The quality criterion for the sprayed composite cermet electric arc coating was the following: minimum porosity parameters; the number of discontinuities at the coating - substrate interface; their hardness.

To determine the capabilities of the modernized electric arc spray gun EM-14M, the parameters of the mode of deposition composite cermet coatings were selected experimentally. The current was varied from 80 to $160 \mathrm{~A}$, the voltage across the arc was from 25 to $35 \mathrm{~V}$, and the powder consumption was 25 to $35 \mathrm{~g} / \mathrm{min}$. The pressure of the compressed air (working and additional) was $0.6 \mathrm{MPa}$, the pressure of the transporting gas was $0.02 \mathrm{MPa}$, the spraying distance was $100 \mathrm{~mm}$.

The stability of the spraying process was assessed by the criterion of arc burning continuity using current and voltage oscillograms. As a result of the selection of the parameters of the spraying mode, it was found that at a current of less than $80 \mathrm{~A}$, a voltage of less than $25 \mathrm{~V}$ and the supply of titanium carbide powder to the arc discharge zone, the process of burning an electric arc becomes unstable. On the oscillogram, the marks of the zero current value were fixed, which indicated an arc rupture, and the zero voltage values about the onset of a short circuit. The arising pulsations of an electric arc lead to the formation of metal droplet-like particles on the sprayed surface, a coarse-grained and loose structure, which is an unacceptable defect in the coating.

With an increase in current over $160 \mathrm{~A}$ and voltage over $35 \mathrm{~V}$, the flow of molten metal particles is divided into two, from each wire-electrode, the enthalpy of molten metal particles increases, which leads to overheating of the substrate and the formation of deposits of molten metal on the coating surface.

A decrease in the distance of spraying, less than $100 \mathrm{~mm}$, also leads to overheating of the substrate and the formation of deposits of molten metal. An increase in the distance of spraying leads to a loss of the particle velocity in a high-temperature jet and their temperature, as a result of which their degree of deformation and bond strength of coatings to the substrate decrease, and porosity increases. An increase in pressure to $0.6 \mathrm{MPa}$ leads to an increase in the coefficient of powder injection into the arc discharge zone; the powder consumption in this mode for a modernized spray gun is $35 \mathrm{~g} / \mathrm{min}$. In this mode, the particle velocity in the high-temperature jet increases and the bond strength of the coatings to the substrate, accordingly, while the porosity decreases. A further increase in pressure will not lead to an increase in the injection coefficient and particle velocity in the high-temperature jet, since in this mode the critical velocity of the compressed air flow from the nozzle is reached. At a pressure of $0.4 \mathrm{MPa}$, the injection coefficient decreases, the powder consumption is $25 \mathrm{~g} / \mathrm{min}$, the spray ability of the jet and the particle velocity decrease, which entails a decrease in the physical and mechanical properties of the coatings.

Using the modernized electric arc spray gun EM-14M, a laboratory batch of samples with different contents of the hardening phase in composite cermet coatings was obtained. Microsections were made to study the microstructure of composite coatings. Metallographic studies (SEM analysis) and determination of the chemical composition by X-ray spectral analysis (EDS analysis) were carried out on a ZEISS Gemini SEM 500 scanning electron microscope. Phase identification and microhardness measurement of composite arc coatings using a PMT-3 microhardness tester on cross sections with a load on the indenter of $100 \mathrm{~g}$.

Fig. 2 shows the microstructures of cermet arc coatings obtained at a current of $120 \mathrm{~A}$ and an arc voltage of $30 \mathrm{~V}$ at different magnifications.

The metallographic analysis of the above microstructures showed that the electric arc composite cermet coating of the steel $65 \mathrm{G}-\mathrm{TiC}$ system has a fairly low porosity, which is about $5 \%$, the structure is well differentiated between particles of dark (presumably titanium carbide) and light (65 G steel) phases.

The phases in the composite cermet electric arc coating were identified by measuring their microhardness (Fig. 3).

The microhardness of the light phase (steel $65 \mathrm{G}$ ) was about $3.2 \mathrm{GPa}$; dark - $31 \mathrm{GPa}(\mathrm{TiC})$, which corresponds to the microhardness of titanium carbide measured with a similar load on the indenter according to work [1]. To confirm our conclusions, an X-ray spectral analysis of the gray phase in the coating was performed (Fig. 4, $a$ ). Its results (Fig. 4, $b$ ) showed that the chemical composition of this phase consists of $19.83 \%$

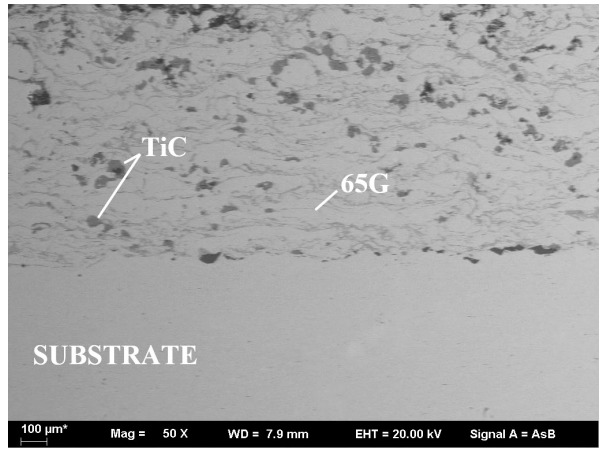

$a$

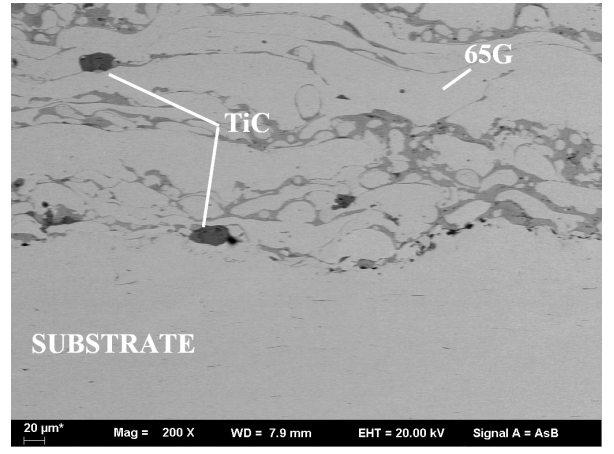

$b$

Fig. 2. Cross section SEM micrographs of electric arc cermet coatings at different magnifications: $a \times 50 ; b \times 200$ 


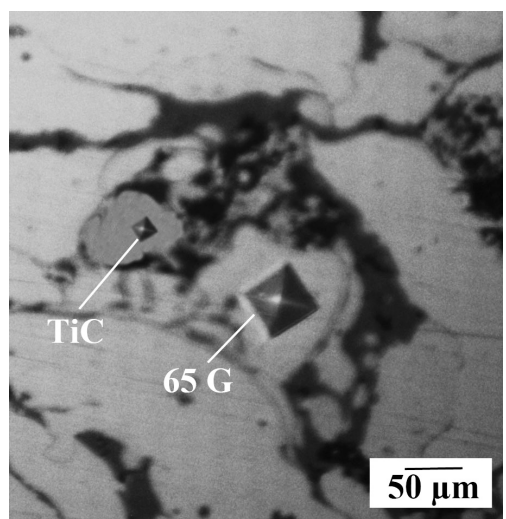

Fig. 3. Microhardness measurement results of different phases in the coating

carbon and $80.17 \%$ titanium. As you know, the molar mass of titanium carbide (TiC) is $59.89 \mathrm{~g} / \mathrm{mol}$. Of these, titanium is $80 \%$ (wt.) $(47.9 \mathrm{~g} / \mathrm{mol})$, and carbon is $20 \%$ (wt.) $(12 \mathrm{~g} / \mathrm{mol})$. Thus, the results obtained correspond to the stoichiometry of this chemical compound and, together with the microhardness indices, confidently give grounds to classify the dark phase as titanium carbide. As a result of measuring the microhardness, it was also found that in cermet electric arc coatings, the microhardness $\mathrm{H} \mu 100$ and the hardness HV5 of the metal matrix increase due to the additional work hardening created by particles of the strengthening phase (TiC). The microhardness $\mathrm{H} \mu 100$ of the metal matrix in cermet coatings increases by $7-9 \%$, the increase in hardness HV5 is $15 \%$.

To obtain optimal physical, mechanical and operational properties in composite electric arc coatings, it is necessary to control the technological modes of spraying, providing given filler content in the corresponding coatings. As a result, depending on the operating conditions of the product and the requirements for the coating, for each specific case, the mode of electric arc spraying is selected experimentally. Analyzing the previous studies [13] on the influence of the technological parameters of electric arc spraying on the quality of the resulting coatings, the following were chosen as the most significant: current, arc voltage and powder consumption. The determination of the content of the carbide phase was carried out by a planimetric method according to the obtained microstructures. The choice of this method is explained by the fact that in

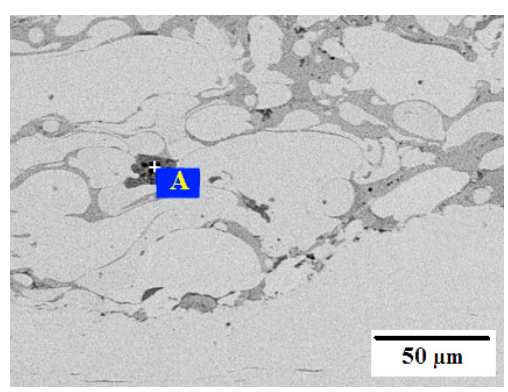

$a$

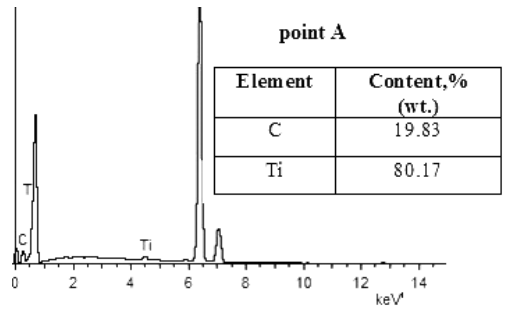

$b$

Fig. 4. EDS analysis area (a) and its results (b) metallographic practice it is quite effective at a low content of the phase under consideration (on the order of several percent), and in such cases it is more accurate than the point and linear methods. Below are the levels of variation of these technological parameters and, accordingly, the amount of the resulting carbide phase (Table).

Analyzing the data presented, it is obvious that the TiC content in the corresponding cermet electric arc coatings increases rapidly with increasing current, voltage, and powder consumption. With an increase in current and voltage, the productivity of the process increases, which leads to an increase in the concentration of molten metal particles in the jet, their enthalpy and, consequently, the content of the filler in the coating. With an increase in the powder consumption, the concentration of powder particles in the high-temperature jet increases, which also leads to an increase in the content of the carbide phase in the cermet coatings. The use of the maximum values of technological parameters, current $160 \mathrm{~A}$, voltage $35 \mathrm{~V}$ and powder consumption $35 \mathrm{~g} / \mathrm{min}$, ensured the content of $25.2 \%$ $\mathrm{TiC}$ in cermet electric arc coatings, but the porosity increased to $9 \%$, including at the coating interface - the substrate.

In the literature $[6,7]$, devoted to the study on the cohesive and bond strength of thermal sprayed coatings, the main attention is paid to the latter. This is, obviously, due to the fact that during the operation of thermal spray coatings, they detach from the base material, and therefore the belief was formed that the bond strength is the limiting parameter. In this work, the pin method was used to determine the bond strength, since it allows one to quickly conduct tests immediately after coating the samples. They were made of quality structural carbon steel 45. General view of the samples is shown in Fig. 5, $a$. Before coating spraying the surface to be sprayed, it was degreased with commercial ethanol and subjected to blastabrasive treatment. The thickness of the applied coatings did not exceed $0.5-0.6 \mathrm{~mm}$. To obtain the results of the bond strength of the coatings to the substrate, spraying in the same mode was performed in one pass on 5 samples simultaneously. The bond strength of the cermet coatings to the substrate was determined using a UMM-5 tensile testing machine. The results of determining the bond strength of sprayed coatings of the steel 65G-TiC system are shown in Fig. 5, $b$.

According to the data presented, the dependence of the bond strength with the substrate on the content of the carbide phase in the coating is extreme. The bond strength of the coating without $\mathrm{TiC}$ is $27 \mathrm{MPa}$. The maximum value of the bond strength $(37 \mathrm{MPa})$ was obtained with a carbide phase content of $18.4 \%$. Since titanium carbide particles have a sufficiently high melting point and hardness, an increase in their bond strength to the substrate is probably due to the fact that unmelted titanium carbide particles, colliding with the substrate surface, additionally activate it due to their high kinetic energy, and colliding with plastic metal particles already fixed, they are introduced into the microroughness of the surface of the substrate and subsequent layers. A decrease in this characteristic with an increase in the $\mathrm{TiC}$ content to $25.2 \%$ is explained by a decrease in the actual contact area of the coating with the substrate.

Thus, based on the results of studies to determine the bond strength, it can be concluded that the optimal content of the

Table

Levels of variation of technological parameters of spraying and the amount of hardening phase in the structure of coatings

\begin{tabular}{|c|c|c|c|}
\hline $\begin{array}{c}\text { Current, } \\
\text { A }\end{array}$ & $\begin{array}{c}\text { Voltage, } \\
\text { V }\end{array}$ & $\begin{array}{c}\text { Powder } \\
\text { consumption, } \\
\text { g/min }\end{array}$ & $\begin{array}{c}\text { The content of the carbide } \\
\text { phase in the coating, } \\
\% \text { (vol.) }\end{array}$ \\
\hline 80 & 25 & 25 & 11.5 \\
\hline 120 & 30 & 30 & 18.4 \\
\hline 160 & 35 & 35 & 25.2 \\
\hline
\end{tabular}




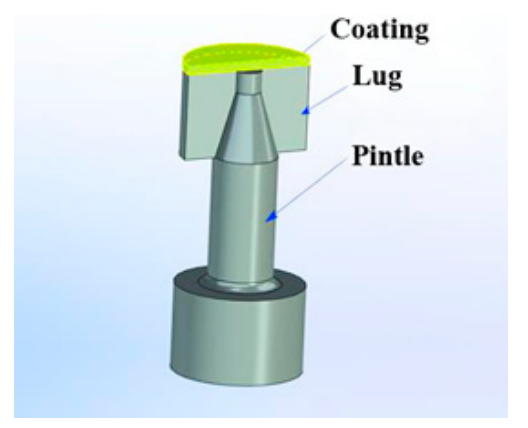

$a$

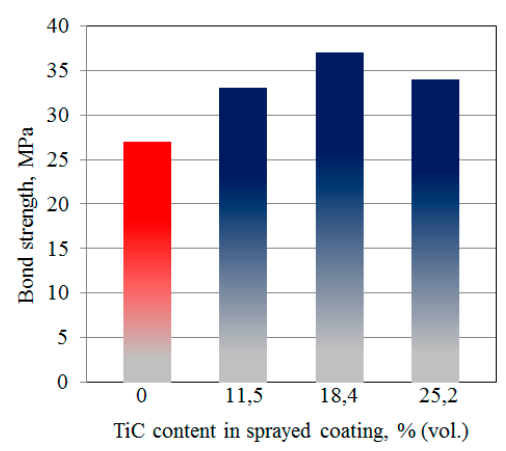

$b$

Fig. 5. General view of samples for determining the bond strength (a) and its measurement results (b)

hardening phase in cermet electric arc coatings is $18.4 \%$ (vol.), while such coatings will have the maximum bond strength to the substrate. The optimal spraying mode for cermet electric arc coatings, providing a hardening phase content of $18.4 \%$ (vol.), is: current $-120 \mathrm{~A}$, voltage $-30 \mathrm{~V}$, powder consumption $-30 \mathrm{~g} / \mathrm{min}$, compressed air pressure (working and additional) $-0.6 \mathrm{MPa}$, transporting gas $-0.02 \mathrm{MPa}$, spraying distance $-100 \mathrm{~mm}$.

\section{Conclusions.}

1. For the first time, electric arc composite cermet coatings of the steel $65 \mathrm{G}-\mathrm{TiC}$ system were obtained using the hardening phase powder in free form due to the use of the modernized electric arc spray gun EM-14M.

2. It has been established that the porosity in cermet arc coatings is about $5 \%$, the microhardness $\mathrm{H} \mu 100$ of the metal matrix increases by $7-9 \%$, the increase in hardness HV5 is $15 \%$ due to the additional hardening of the hardening phase (TiC) particles.

3 . The influence of the technological parameters of spraying on the amount of the hardening phase (TiC) in the structure of the coating and its content on their bond strength to the substrate has been determined. The maximum value of the bond strength to the substrate (37 MPa) was obtained at a carbide phase content of $18.4 \%$ (vol.).

4. Thus, the electric arc spraying method was further developed by expanding the possibilities of creating composite cermet coatings due to the formation of a heterophase jet by feeding a hardening phase powder into the high-temperature zone of the spraying gun using a modernized design of the spray head and developing the technological basis for their deposition.

5. Further research prospects are in the establishment of new patterns and optimization of the process of deposition cermet electric arc coatings, as well as in determining their wear resistance.

References.

1. Borisov, Y.S., Borisova, A. L., Kolomytsev, M.V., \& Masyuchok, O. P. (2017). High-Velocity Air Plasma Spraying of (Ti, Cr)
C-32 wt.\% Ni Clad Powder. Powder Metallurgy and Metal Ceramics, 56, 305-315. https://doi.org/10.1007/s11106-017-9898-0. 2. Zhu, H., Li, H., \& Li, Z. (2013). Plasma sprayed TiB2-Ni cermet coatings: Effect of feedstock characteristics on the microstructure and tribological performance. Surface and coating technology, 235, 620627. https://doi.org/10.1016/i.surfcoat.2013.08.040.

3. Vasileios, K., Kamnis, S., Allcock, B., \& Sai, Gu (2019). Effects and interplays of spray angle and stand-off distance on the sliding wear behavior of HVOF WC-17Co coatings. Journal of thermal spray technology, 28, 514534. https://doi. org/10.1007/s11666-019-00831-X.

4. Xie, X., Yin, F., Wang, X., Ouyang, X., Li, M., \& Hu, J. (2019). Corrosion Resistance to Molten Zinc of a Novel Cermet Coating Deposited by Activated Combustion High-Velocity Air Fuel (AC-HVAF). Journal of thermal spray technology, 28, 1252-1262. https://doi.org/10.1007/s11666-019-00893-x. 5. Vijay, S., Wang, L., Lyphout, L., Nylen, P., \& Markocsan, N. (2019). Surface characteristics investigation of HVAF sprayed cermet coatings. Surface and coatings technology, 493, 956-962. https://doi.org/10.1016/j.apsusc.2019.07.079.

6. Fernandez, R., \& Jodoin, B. (2018). Cold spray aluminumalumina cermet coatings: effect of alumina content. Journal of thermal spray technology, 27, 603-623. https://doi.org/10.1007/ s11666-019-00845-5.

7. Winnicki, M., Małachowska, A., Piwowarczyk, T., Rutkowska-Gorczyca, M., \& Ambroziak, A. (2016). The bond strength of $\mathrm{Al}+\mathrm{Al}_{2} \mathrm{O}_{3}$ cermet coatings deposited by low-pressure cold spraying. Surface and coatings technology, 16, 743752. https://doi.org/10.1016/i.acme.2016.04.014.

8. Lima, C., Libardi, R., Camargo, R., Fals, H., \& Ferraresi, V. (2014). Assessment of abrasive wear of nanostructured WC-Co and Fe-based coatings applied by HP-HVOF, flame, and wire arc spray. Journal of thermal spray technology, 23, 10971104. https://doi.org/10.1007/s11666-014-0101-6.

9. Wielage, B., Pokhmurska, H., Student, M., Gvozdeckii, V., Stupnyckyj, T., \& Pokhmurskii, V. (2013). Iron-based coatings arc-sprayed with cored wires for applications at elevated temperatures. Surface and coatings technology, 220, 27-35. https:// doi.org/10.1016/j.surfcoat.2012.12.013.

10. Sheppard, P., \& Koiprasert, H. (2014). Effect of W dissolution in NiCrBSi-WC and NiBSi-WC arc sprayed coatings on wear behaviors. Surface and coatings technology, 317, 194200. https://doi.org/10.1016/j.wear.2014.06.008.

11. Dubovyi, O. M., Karpechenko, A.A., Bobrov, M. M., \& Mazurenko, A. O. (2016). Device for electric arc spraying of composite coatings. (Ukrainian Patent No. 111760). Kyiv: Ukrainian Intellectual Property Institute.

12. Dubovyi, O. M., Karpechenko, A.A., Bobrov, M.M., \& Labartkava, A. V. (2020). Development of Thermal Spray Technology of Forming a Crushed Polygonization Nanosized Substructure. Metallophysics and Advanced Technologies, 4, 631-653. https://doi.org/10.15407/mfint.42.05.0631.

\section{Електродугове напилення керметних покриттів системи сталь 65 Г-ТіC}

\section{О. М. Дубовий ${ }^{1}$, А. А. Карпеченко ${ }^{1}$, М. М. Бобров ${ }^{1}$ О. С. Герасін ${ }^{1}$, О. О. Лимар 2}

1 - Національній університет кораблебудування імені адмірала Макарова, м. Миколаїв, Україна, е-mail: laborantmtm@gmail.com

2 - Миколаївський національний аграрний університет, м. Миколаїв, Україна

Мета. Обгрунтування можливості отримання композиційних керметних електродугових покриттів із застосуванням в якості зміцнюючої фази порошку ТiC, визначення їх фізико-механічних властивостей. 
Методика. Дослідження мікроструктури композиційних керметних електродугових покриттів здійснювали методами комп'ютерної металографії за допомогою скануючого електронного мікроскопа ZEISS Gemini SEM 500. Хімічний склад визначали методом рентгеноспектрального аналізу, ідентифікацію фаз проводили шляхом вимірювання їх мікротвердості на приладі ПМТ-3. Міцність зчеплення отриманих покриттів з основою визначали методом «витягування конусного штифта» на розривній машині УММ-5.

Результати. Отримані композиційні керметні покриття системи сталь 65 Г-ТіС електродуговим методом 3 використанням порошку ТiC у вільному вигляді. Встановлено вплив технологічних параметрів напилення на кількість карбідної фази в покритті, досліджена її мікроструктура. Визначена пористість, мікротвердість фаз у покритті та їх міцність зчеплення з основою.

Наукова новизна. Уперше отримані композиційні керметні електродугові покриття системи сталь 65Г-ТіС шляхом застосування порошку зміцнювальної фази у вільному вигляді. Досліджена їх мікроструктура, мікротвердість і міцність зчеплення з основою. Встановлені технологічні режими нанесення електродугових покриттів, що забезпечують оптимальний вміст зміцнювальної фази для досягнення їх максимальної міцності зчеплення з основою.

Практична значимість. Застосування результатів досліджень, отриманих у роботі, а саме визначення оптимальних технологічних параметрів напилення для формування керметних електродугових покриттів 3 максимальним рівнем фізико-механічних і експлуатаційних властивостей, надає можливість задовольняти вимоги, що пред'являються до відновлення та зміцнення зношених поверхонь. Це призводить до підвищення терміну експлуатації деталей не тільки в гірничодобувній, але й в інших галузях промисловості.

Ключові слова: електродугове напилення, керметні покриття, карбід титану

\section{Электродуговое напыление керметных покрытий системы сталь 65Г-ТіC}

\author{
А. Н. Дубовой ${ }^{1}$, А. А. Карпеченко ${ }^{1}$, М. Н. Бобров ${ }^{1}$, \\ А. С. Герасин ${ }^{1}$, А. А. Лимарь
}

1 - Национальный университет кораблестроения имени адмирала Макарова, г. Николаев, Украина, e-mail: laborantmtm@gmail.com

2 - Николаевский национальный аграрный университет, г. Николаев, Украина
Цель. Обоснование возможности получения композиционных керметных электродуговых покрытий с применением в качестве упрочняюшей фазы порошка $\mathrm{TiC}$, определение их физико-механических свойств.

Методика. Исследование микроструктуры композиционных керметных электродуговых покрытий осуществляли методами компьютерной металлографии при помощи сканирующего электронного микроскопа ZEISS Gemini SEM 500. Химический состав определяли методом рентгеноспектрального анализа, идентификацию фаз проводили путем измерения их микротвердости на приборе ПМТ-3. Прочность сцепления полученных покрытий с основой определяли методом «вытягивания конусного штифта» на разрывной машине УММ-5.

Результаты. Получены композиционные керметные покрытия системы сталь 65 Г-ТіС электродуговым методом с использованием порошка ТіС в свободном виде. Установлено влияние технологических параметров напыления на количество карбидной фазы в покрытии, исследована ее микроструктура. Определены пористость, микротвердость фаз в покрытии и его прочность сцепления с основой.

Научная новизна. Впервые получены композиционные керметные электродуговые покрытия системы сталь 65 Г-ТіС путем применения порошка упрочняющей фазы в свободном виде. Исследованы их микроструктура, микротвердость и прочность сцепления с основой. Установлены технологические режимы нанесения электродуговых покрытий, обеспечивающие оптимальное содержание упрочняющей фазы для достижения их максимальной прочности сцепления с основой.

Практическая значимость. Применение результатов исследований, полученных в работе, а именно определение оптимальных технологических параметров напыления для формирования керметных электродуговых покрытий с максимальным уровнем физико-механических и эксплуатационных свойств, предоставляет возможность удовлетворять предъявляемые требования к восстановлению и упрочнению изношенных поверхностей. Это приводит к повышению срока эксплуатации деталей не только в горнодобываюшей, но и в других отраслях промышленности.

Ключевые слова: электродуговое напыление, керметные покрытия, карбид титан

Recommended for publication by V.F. Kvasnytskyi, Doctor of Technical Sciences. The manuscript was submitted 08.09.20. 